\title{
In vitro Nasal Cell Culture Systems for Drug Transport Studies
}

\author{
Hyun-Jong Cho', Ubonvan Termsarasab ${ }^{1}$, Jung Sun Kim² and Dae-Duk Kim ${ }^{1 \dagger}$ \\ ${ }^{1}$ College of Pharmacy, Seoul National University, Seoul 151-742, South Korea \\ ${ }^{2}$ Division of Health Science, Dongseo University, Busan 617-716, Korea \\ (Received November 21, $2010 \cdot$ Revised December 13, $2010 \cdot$ Accepted December 14, 2010)
}

\begin{abstract}
Growing interest in the nasal route as a drug delivery system calls for a reliable in vitro model which is crucial for efficiently evaluating drug transport through the nasal cells. Various in vitro cell culture systems has thus been developed to displace the ex vivo excised nasal tissue and in vivo animal models. Due to species difference, results from animal studies are not sufficient for estimating the drug absorption kinetics in humans. However, the difficulty in obtaining reliable human tissue source limits the use of primary culture of human nasal epithelial cells. This shortage of human nasal tissue has therefore prompted studies on the "passage" culture of nasal epithelial cells. A serially passaged primary human nasal epithelial cell monolayer system developed by the air-liquid interface (ALI) culture is known to promote the differentiation of cilia and mucin gene and maintain high TEER values. Recent studies on the in vitro nasal cell culture systems for drug transport studies are reviewed in this article.
\end{abstract}

Key words - Human nasal epithelial cell, Cell monolayer system, Drug transport study, Cell culture condition, Nasal drug delivery

Intranasal route for drug delivery has gained much interest as a non-invasive administration route. Diverse drug types, including small molecule type chemicals (Cho et al., 2008; Huh et al., 2010), peptides (Chen et al., 2009; Yu and Kim, 2009), proteins (Jintapattanakit et al., 2010; Leitner et al, 2004), and nucleic acids (Bitko and Barik, 2008; Howard et al., 2006; Vetter et al., 2010), have been attempted for administration via the nasal route for local as well as systemic delivery. Nasal delivery has several advantages, which include rapid onset of action, non-invasiveness, avoidance of hepatic and intestinal first-pass metabolism, and self-medication (Costantino et al., 2007; Pires et al., 2009). However, several drawbacks should be considered during the formulation process: i.e., limited residence time (15 30 min) due to drug elimination by mucociliary clearance, limited administration volume $(25 \sim 200 \mu \mathrm{L})$, low permeability of high molecular weight drugs $(>1 \mathrm{kDa})$, physical barrier of epithelium and mucus layer and irritancy for the nasal epithelium (Arora et al., 2002; Marttin et al., 1998; Schmidt et al., 1998; Witschi and Mrsny, 1999).

For efficiently evaluating the nasal delivery systems, reliable in vitro and in vivo models are essential. In vivo animal models or ex vivo excised animal tissue models have frequently uti- lized rats, rabbits, dogs, sheeps and monkeys. However, results obtained from these animals did not correlate well with those of humans due to species differences in terms of the anatomical structure, making difficult the estimation of drug absorption kinetics in humans. Moreover, limitation in research using experimental animals is also due to regulatory issues and ethical considerations. (Hosoya et al., 1994; Lang et al., 1996; Wadell et al., 2003).

Cell culture systems of human nasal epithelium based on primary culture technologies have therefore have been established to replace animal models. These systems are known to be extremely useful for the study of nasal epithelial permeability and drug absorption (Wadell et al., 1999; Werner and Kissel, 1995). Nasal cells originated from man may endow more clinical relevance. However, difficulty in obtaining reliable human tissue sources is a limiting factor that hinders the widespread usage of this in vitro primary nasal cell culture system. Thus, the shortage of human nasal tissue has prompted studies on the passage culture of nasal epithelial cells for in vitro drug transport studies. In the current review, recently developed in vitro nasal cell culture systems will be introduced, followed by their application for drug transport studies.

\footnotetext{
'Corresponding Author :

Tel : +82-2-880-7870, E-mail : ddkim@snu.ac.kr

DOI : $10.4333 /$ KPS.2010.40.6.321
} 


\section{Primary Culture of Human Nasal Epithelial Cells}

\section{Characteristics of primary nasal cells}

Human nasal tissue can be obtained by atraumatic, traumatic and post mortem methods (Schmidt et al., 1998). In general, specimens of human nasal tissues can be acquired from patients going through endonasal surgery to remove nasal polyps, septum deviation and nasal reconstruction. The nasal epithelial cells after being isolated from these nasal tissues are consequently cultured. However, despite being a promising tool for drug permeation study, metabolism study, toxicological study and electrophysiological study, this primary human nasal cell culture has several limitations. They are donor-todonor variability, limited amount of tissues obtained from one donor, fastidious culturing method, the probability of contamination by pathogen and heterogeneity during culture and limited use of passage number (Schmidt et al., 1998; Yoon et al., 2000). In spite of these disadvantages, the nasal cell from primary culture is deemed more appropriate for drug transport studies compared to other cells due to the formation of confluent monolayers and differentiation into goblet and ciliated cell. Several factors regarding the culture conditions have to be considered carefully to optimize the primary human nasal epithelial cell culture system.

\section{Origin of nasal tissue and cells}

Human nasal tissues or cells can be obtained from different regions of the nasal cavity: 1) the vestibular area, covered with a stratified, keratinized and squamous epithelium; 2) the atrium, an intermediated zone between squamous anterior part and microvilli in posterior part; 3) superior, medium and inferior turbinates, pseudostratified columnar epithelium with cilia; 4) the olfactory epithelium between the nasal septum and the lateral wall of the nasal passage (Cornaz and Buri, 1994). For the drug transport study, the pseudostratified ciliated columnar epithelium is most appropriate and is composed of 1) the nonciliated columnar cells with microvilli, 2) the goblet cells, 3) the basal cells, and 4) the ciliated columnar cells. Selecting the optimal extraction region is very important for the establishment of a cell culture system for drug permeation study. It is known that the junctions between the ciliated columnar cells are tighter than between the goblet cells themselves or between goblet cells and ciliated columnar cells (Wüthrich and Buri, 1989). As enzymes for drug metabolism are expressed abundantly in olfactory epithelium than in the respiratory epithelium, the former is more suitable for drug metabolism study (Gervasi et al., 1991; Minn et al., 2002; Sarkar, 1992). Thus, the region where the cells are isolated has to be restricted to the specific site where the drug is applied to.

Although polyps have been used as the source of nasal epithelial cells, they show abnormally enhanced $\mathrm{Na}^{+}$and $\mathrm{Cl}^{-}$ion permeation compared to normal tissues from turbinates (Bernstein and Yankaskas, 1994). Therefore pseudostratified ciliated columnar epithelium from medium and inferior turbinates from healthy persons is preferred and strongly recommended for consequent cell cultures for drug permeation study.

\section{Sampling technique for nasal cells from tissue}

There are three kinds of human nasal specimen acquiring techniques; atraumatic, traumatic and post mortem method (Table I). Blown secretion, nasal smears, nasal lavage, scraping, brushing and imprint are typical atraumatic techniques.

Table I. Classification of Methods for Obtaining Human Nasal Specimen

\begin{tabular}{|c|c|c|}
\hline Method & Specific technique & References \\
\hline \multirow{6}{*}{$\begin{array}{l}\text { Atraumatic } \\
\text { method }\end{array}$} & Blown secretion & - \\
\hline & Nasal smears & - \\
\hline & Nasal lavage & $\begin{array}{l}\text { Pipkorn et al. (1988), } \\
\text { Pipkorn and Karlsson (1988) }\end{array}$ \\
\hline & Scraping & $\begin{array}{l}\text { Agu et al. (2009), } \\
\text { Alford et al. (1969), } \\
\text { Otsuka et al. (1987), } \\
\text { Pipkorn et al. (1988), } \\
\text { Pipkorn and Karlsson (1988), } \\
\text { Zhou et al. (2009) }\end{array}$ \\
\hline & Brushing & $\begin{array}{l}\text { Pipkorn et al. (1988), } \\
\text { Hull and Harris (1994) }\end{array}$ \\
\hline & Imprint & - \\
\hline \multirow[t]{3}{*}{$\begin{array}{l}\text { Traumatic } \\
\text { method }\end{array}$} & Polyp-ectomy & $\begin{array}{l}\text { Hanamure et al. (1994), } \\
\text { Hofmann et al. (2010), } \\
\text { Lazard et al. (2009), } \\
\text { Vetter et al. (2010) }\end{array}$ \\
\hline & Turbin-ectomy & $\begin{array}{l}\text { Koizumi et al. (2008), } \\
\text { Noruddin et al. (2007), } \\
\text { Steele and Arnold (1985), } \\
\text { Suptawiwat et al. (2010), } \\
\text { Wilk-Blaszczak et al. (1992), } \\
\text { Yeo and Jang (2010) }\end{array}$ \\
\hline & Surgical biopsy & $\begin{array}{l}\text { Boucher et al. (1988), } \\
\text { Han et al. (2009), } \\
\text { Mallants et al. (2009), } \\
\text { Slütter et al. (2010), } \\
\text { Agu et al. (2000), } \\
\text { Zuckerman et al. (2008) }\end{array}$ \\
\hline \multirow{2}{*}{$\begin{array}{l}\text { Post mortem } \\
\text { method }\end{array}$} & Autopsy & Gruenert et al. (1990) \\
\hline & Dissection & Coste et al. (1996) \\
\hline
\end{tabular}

This table is a modified and supplemented version of previous reports (Schmidt et al., 1998). 
Since the passage number of human nasal cell is known to be generally two or three subsequent passages (Wu et al., 1985), the atraumatic method which can provide repeated sampling from identical donors is preferred. However, atraumatic methods like the blown secretion and nasal smears techniques which provide cells by mechanical detachment with mild strength, such as rubbing with swab, cannot provide sufficiently large number of cells for confluent cell culture. Moreover, according to the lavage method, although enough sample can be obtained, the sampling region cannot be modulated (Pipkorn et al., 1988; Pipkorn and Karlsson, 1988). Here, detached nasal cells can be harvested after rinsing both nostrils with physiological saline. On the other hand, the scraping method can be performed with a sharp curette without anesthesia and achieve accurate sampling location, repeated sampling work, stripping out only epithelium and gaining sufficient amount of cells (Agu et al., 2009; Alford et al., 1969; Otsuka et al., 1987; Pipkorn et al., 1988; Pipkorn and Karlsson, 1988; Zhou et al., 2009). In the case of the brushing techniques, cells can be obtained by rotating a small nylon brush in the epithelium and soaking procedure (Pipkorn et al., 1988). However, it was reported that this method was unsuitable for the use in the diffusion chamber and in electrophysiological studies (Hull and Harris, 1994). In an imprint method, thin plastic strips with sticky surface is introduced into mucosal membrane to collect nasal epithelial cells. Although large amount of cells can be acquired and specific region can be determined, disadvantage of this technique is that mucus on the sticky surface may hamper the dissociation of cells. Traumatic methods when compared to atraumatic methods may be able to provide more amounts of nasal specimens. However, local or general anesthesia during the sampling process is inevitable. Therefore, overall, atraumatic methods can be regarded as a prime choice in the aspect of repeatedly collecting nasal specimens and providing reproducible results in drug permeation study.

\section{Factors affecting primary cell culture system}

Primary nasal epithelial cell culture can be affected by various factors as summarized in Table II. Human nasal epithelial cells are grown in and affected by various supporting materials such as plate culture dish, cover slips, polymer membranes, collagen matrices, and collagen gels. The surface type may give obvious impacts on the specific function and phenotypic properties of human nasal cells during the culture period. Therefore, selection of optimal supporting material should meet the objective of the investigation. For example, plastic dish makes attaching and growing rapidly to confluent cell
Table II. Factors Affecting the Primary Nasal Epithelial Culture

\begin{tabular}{|c|c|c|}
\hline \multicolumn{2}{|c|}{ Factors } & Specification and remark \\
\hline \multirow{4}{*}{$\begin{array}{l}\text { Supporting } \\
\text { membranes }\end{array}$} & Plate culture dish & - \\
\hline & Cover slips & - \\
\hline & $\begin{array}{l}\text { Porous polymer } \\
\text { membrane }\end{array}$ & $\begin{array}{l}\text { Polyethylene terephthalate } \\
\text { Polycarbonate } \\
\text { Polyester }\end{array}$ \\
\hline & Collagen matrices & $\begin{array}{l}\text { Collagen coated support } \\
\text { Collagen gel }\end{array}$ \\
\hline \multirow[t]{2}{*}{$\begin{array}{l}\text { Medium } \\
\text { composition }\end{array}$} & Culture medium & $\begin{array}{l}\text { DMEM } \\
\text { Ham's F-12 } \\
\text { BEGM } \\
\text { DMEM:Ham's F-12 (1:1) } \\
\text { BEGM:DMEM }(1: 1) \\
\text { BEGM:DMEM/F-12 (1:1) }\end{array}$ \\
\hline & Supplements & $\begin{array}{l}\text { Serum } \\
\text { Antibiotics and fungicides } \\
\text { Hormones } \\
\text { Growth factors } \\
\text { Retinoids }\end{array}$ \\
\hline Seeding density & & - \\
\hline Culturing period & & $\begin{array}{l}\text { Influence on the } \\
\text { tight junction and cilia } \\
\text { formation }\end{array}$ \\
\hline $\begin{array}{l}\text { Feeding } \\
\text { method and } \\
\text { culture condition }\end{array}$ & $\begin{array}{l}\text { LCC } \\
\text { ALI }\end{array}$ & $\begin{array}{l}\text { Influence on the } \\
\text { tight junction and cilia } \\
\text { formation }\end{array}$ \\
\hline Passage number & & $\begin{array}{l}\text { Maximum } 2 \text { to } 3 \text { for } \\
\text { primary cell }\end{array}$ \\
\hline
\end{tabular}

monolayer possible. As culturing time proceeds, the cells become flat and squamous, loose cilia and secretory granules and are apt to be detached (Boucher et al., 1987). For drug transport studies, confluent nasal epithelial cells on the plate dish have to be seeded onto porous polymer membranes. The results of drug permeation studies depend on the confluency of nasal epithelial cell monolayers. Polymer membranes that can be used include polyethyleneterephthalate (Werner and Kissel, 1995, 1996), polycarbonate (Kienast et al., 1994) and polyester (Gray et al., 2001; Huh et al., 2010; Cho et al., 2010). Among commercially available polymer supports, the microscopic observation of cells cultured on the translucent polymer membrane is difficult to be acquired. Therefore, transepithelial electrical resistance (TEER) value measurement or transport study of hydrophilic markers (i.e., mannitol) is recommended instead. In other investigations, transparent polymer membranes (i.e., polyester membrane) have been used for cell monolayer culture and microscopic observation (Huh et al., 2010; Cho et al., 2010). Collagen coating or collagen layer also has an effect on the nasal cell differentiation during culture on the supporting material. Extracellular matrix, composed of col- 
lagen, glycosaminoglycans and glycoproteins, can influence cell differentiation, proliferation and migration during nasal cell culture (De Fraissinette et al., 1995). However, the effect of collagen during the nasal cell culture is still controversial. It was reported that collagen gel, of which thickness was more than $1 \mathrm{~mm}$ could produce more pseudostratified cells (Robinson and Wu, 1993). However, in other reports (Werner and Kissel, 1995; Wu et al., 1985), collagen-coated supports provided similar or less cell growth and differentiation compared to uncoated supports. In recent studies, Cellagen ${ }^{\circledR}$ CD-24 inserts were successfully used in drug transport studies (Agu et al.,001) and exhibited good epithelial differentiated phenotype (Agu et al., 2004).

Cell culture media and supplements also affect the attachment, proliferation and differentiation of nasal epithelial cell. Various culture media and supplements are presented in Table II. For the human nasal epithelial cell culture, Ham's F-12 (Wu et al., 1985; Yankaskas et al., 1985), Bronchial epithelial growth medium (BEGM)/Dulbecco's modified Eagle's medium (DMEM) (Chen et al., 2001), BEGM (Koizumi et al., 2008), Ham's F12/DMEM (Agu et al., 2004; Mallant et al., 2009; Werner and Kissel, 1995), DMEM (Agu et al., 2001; Yoo et al., 2003) and BEGM/DMEM-F12 (Huh et al., 2010; Lee et al., 2005) have been used. Serum may also be added into the cell culture media, but it may induce variability in cell growth and squamous differentiation. The use of serum at the initial stage $(<24 \mathrm{~h})$ was good for cell attachment but longer incubation reduced the proliferation and induced squamous differentiation (Boucher et al., 1987; Usui et al., 2000; Wu et al., 1985). Synthetic serum, Ultroser G (2\%), has been widely used as an alternative for serum (Dimova et al., 2005; Hoang et al., 2002; Mallant et al., 2008). Serum-free media is also preferred due to the absence of variability in cell growth. It can produce comparable cell differentiation, growth and tight junction formation (Lee et al., 2005; Lin et al., 2005; Lin et al., 2007a). Hormones and growth factors, such as insulin, hydrocortisone, triiodothyronine, epidermal growth factor, retinoic acid and transferrin, are commonly added to improve growth or cell differentiation. Antibiotics and fungicides are also added to the culture media to prevent bacteria and yeast infection. Penicillin $(50 \sim 100 \mathrm{IU} / \mathrm{mL})$ and streptomycin $(50 \sim 100 \mu \mathrm{g} /$ $\mathrm{mL}$ ) are the most common antibiotics but gentamycin, amphotericin, ciprofloxacin and tobramycin have also been used. Other factors including cell seeding density, culturing period and feeding condition, can also influence the human nasal epithelial cell culture system (Lee et al., 2005; Yoo et al., 2003).

\section{Cell Line Systems}

\section{Characteristics of cell lines and their culture models}

Using the right cell lines can enhance proliferation and improve-usage period at costs that are relatively low providing reproducible results. The properties of cell culture systems of cell lines are summarized in Table III. BT (from bovine turbinates), NAS 2BL (from rat nasal squamous carcinoma), Calu-3, 16HBE14o and RPMI 2650 are commonly used. Among these, only RPMI 2650 is originated from the human nasal tissue, human nasal squamous cell carcinoma of the nasal septum. However, this cell line has the following major drawbacks: 1) no expression of goblet and ciliated cells and 2) no

Table III. Summary of in vitro Nasal Cell Culture Models for Nasal Drug Transport Study

\begin{tabular}{|c|c|c|c|c|}
\hline & Name of cell line & Origin & Advantages and disadvantages & References \\
\hline \multirow[t]{5}{*}{ Cell line } & BT & Bovine turbinates & Origin: bovine turbinates & Werner and Kissel, 1996 \\
\hline & NAS 2BL & $\begin{array}{l}\text { Rat nasal } \\
\text { squamous carcinoma }\end{array}$ & -Origin: rat nasal carcinoma & Hood et al., 1987 \\
\hline & Calu-3 & $\begin{array}{l}\text { Human lung } \\
\text { adenocarcinoma }\end{array}$ & $\begin{array}{l}\text {-Sufficient TEER values for drug transport } \\
\text { study } \\
\text {-Origin: lung carcinoma }\end{array}$ & $\begin{array}{l}\text { Foster et al., 2000, } \\
\text { Mathia et al., 2002, } \\
\text { Teijeiro-Osorio et al., } 2009\end{array}$ \\
\hline & $16 \mathrm{HBE} 14 \mathrm{o}^{-}$ & $\begin{array}{l}\text { Human normal bronchial } \\
\text { epithelium of male heart } \\
\text { lung transplant patient }\end{array}$ & $\begin{array}{l}\text {-Sufficient TEER values under certain } \\
\text { culture condition for drug transport study } \\
\text {-Origin: bronchial epithelium }\end{array}$ & $\begin{array}{l}\text { Manford et al., } 2005 \text {, } \\
\text { Yang et al., } 2004\end{array}$ \\
\hline & RPMI 2650 & $\begin{array}{l}\text { Human nasal squamous } \\
\text { cell carcinoma of the } \\
\text { nasal septum }\end{array}$ & $\begin{array}{l}\text { No expression of goblet and ciliated cells } \\
\text { and no formation of tight junction } \\
\cdot \text { Pertinency for metabolism studies }\end{array}$ & $\begin{array}{l}\text { Bai et al., 2008, } \\
\text { Wengst and Reichl, 2010, } \\
\text { Berger et al., 1999, } \\
\text { Werner and Kissel, } 1995\end{array}$ \\
\hline Primary cell & $\begin{array}{l}\text { Human nasal } \\
\text { epithelial cell }\end{array}$ & Human turbinates & $\begin{array}{l}\text { Differentiation of cilia and mucin gene } \\
\text { under ALI condition } \\
\text {-Sufficient TEER values for drug transport } \\
\text { study } \\
\text { - Limited passage number }\end{array}$ & $\begin{array}{l}\text { Lee et al., } 2005, \\
\text { Lin et al., 2007, } \\
\text { Roh et al., } 1999 \\
\text { Wu et al., } 1985, \\
\text { Yoo et al., } 2003\end{array}$ \\
\hline
\end{tabular}


formation of confluent cell monolayers (Schmidt et al., 1998; Werner and Kissel, 1996). The lack of monolayer formation makes this cell line unusable for drug transport study. However, as some kinds of aminopeptidases are expressed in this cell line, it may be useful for metabolism studies (Berger et al., 1999; Werner and Kissel, 1995). Calu-3 cells can develop polarized monolayers and suitable TEER value for transport study. However, its origin is not normal nasal epithelium (Foster et al., 2000; Mathia et al., 2002). 16HBE14o- cell line has also shown maximally $533 \sim 791 \Omega \cdot \mathrm{cm}^{2}$ of TEER value in submerged culture condition, but this cell line is a SV40 large Tantigen transformed epithelial cell line originating from the normal bronchial epithelium of 1-year-old male heart lung transplant patient (Cozens et al., 1994; Ehrhardt et al., 2002).

\section{Application to drug transport study}

Although RPMI 2650 cell line is known to be unsuitable for drug permeation study, its application for drug transport study has been reported. RPMI 2650 cells formed confluent cell monolayer and developed enough TEER values under ALI culture condition (Bai et al., 2008). The highest TEER values $\left(192 \pm 3 \Omega \cdot \mathrm{cm}^{2}\right)$ were observed under the following culture conditions: collagen-coated polytetrafluoroethylene inserts, ALI culture condition for 10 days and a seeding density of $4 \times 10^{5}$ cells $/ \mathrm{cm}^{2}$. The expression of four tight junction proteins (ZO-1, occludin, claudin-1 and E-cadherin) was also identified. This cell monolayer system was used for evaluating the permeation of spray-dried mucoadhesive microspheres (Harikarnpakdee et al., 2006). Recently, a three-dimensional construct of the human nasal mucosa composed of a collagen matrix with embedded human nasal fibroblasts, covered by a RPMI 2650 cell layer, was developed (Wengst and Reichl, 2010). The three-dimensional reconstructed nasal mucosa exhibited comparable permeation barrier properties and fouror five-times faster paracellular permeation rates compared to the epithelial cell model. In case of the Calu-3 cell which is known to be a lung adenocarcinoma cell line, wide use in the in vitro nasal drug permeation studies of small chemicals (Amoako-Tuffour et al, 2009) and macromolecules (Amidi et al., 2006; Li et al., 2006; Seki et al., 2007; Teijeiro-Osorio et al., 2009) have been reported.

\section{Nasal Epithelial Cell Monolayer System for Drug Transport Study}

\section{Serially passaged human nasal epithelial cell mono- layers}

For drug transport and metabolism studies in the human nasal epithelial cells, established cell culture conditions which were relatively simple have been utilized (Werner and Kissel, 1995; Werner and Kissel, 1996) as in the case of insulin and peptide studies (Agu et al., 2002; Kissel and Werner, 1998; Vu Dang et al., 2002). However, these cell culture systems yielded only small amounts of nasal tissue and were accompanied with the feasibility of pathogen contamination and large donor-todonor variability (Gray et al., 1996). It was therefore inevitable to introduce a serially passaged system to overcome these limitations. Serial culture up to passage 6 has been conducted and cells up to passage 4 seemed to be suitable for subculturing because passage 5 and 6 cells induced swollen and lysed morphology as well as improper growth in permeable supports (Yoo et al., 2003).

\section{Characterization of human nasal epithelial cell mono- layers}

The culture conditions of the serially passaged primary human nasal epithelial cell monolayer can be classified into the liquid-covered culture (LCC) and the air-liquid interface (ALI) type. The characteristics of the two culture conditions are presented in Table IV. It has been observed that culture conditions affected the results in terms of altered differentiation and tight junction formation in drug transport studies.

Mucin secretion in a passaged culture of primary human respiratory epithelial cells had already been identified in LCC culture conditions (Wu et al., 1985; Roh et al., 1999). However, the development of a serially passaged primary human nasal epithelial cell monolayer system for drug transport study was reported more recently (Yoo et al., 2003) in which the formation of a tight junction was considered as the most important factor. Serially passaged human nasal epithelial cells were grown as confluent monolayers on Transwell ${ }^{\circledR}$ insert under LCC condition. Maximum TEER value $\left(1,963 \pm 413 \Omega \cdot \mathrm{cm}^{2}\right)$ was measured on day 2 and then decreased rapidly (Lee et al., 2005). According to morphological characteristics observed by scanning electron microscopy (SEM), denuded and flattened ciliated cells and numerable microvillus were observed for 3 weeks. Mucin gene expression was weaker under LCC condition than under ALI condition. Tight junction formation was observed by the staining of actin filaments and TEM images. Apparent permeability coefficients $\left(\mathrm{P}_{\text {app }}\right)$ were measured with $\left[{ }^{14} \mathrm{C}\right]$ mannitol, a hydrophilic substances, and budesonide, a hydrophobic substance, according to the various TEER values. Permeability of $\left[{ }^{14} \mathrm{C}\right]$ mannitol showed good correlation with the results of freshly excised tissue. Constant $\mathrm{P}_{\text {app }}$ values of budesonide independent on the TEER values indicated that transcellular route is the major permeation route for lipophilic 
Table IV. Comparison of LCC and ALI Culture Condition of Primary Human Nasal Epithelial Cell Monolayer for Nasal Drug Transport Study

\begin{tabular}{|c|c|c|}
\hline & $\mathrm{LCC}$ & ALI \\
\hline Cell culture media & DMEM including $10 \% \mathrm{FBS}$ & BEGM/DMEM-F12 (50:50) \\
\hline Culturing method & $\begin{array}{l}\text { Both apical and basolateral sides are filled with cell } \\
\text { culture medium, which is changed after } 24 \mathrm{~h} \text { of } \\
\text { seeding and then every } 2 \text { days thereafter. }\end{array}$ & $\begin{array}{l}\text { Both sides are changed after } 24 \text { and } 72 \mathrm{~h} \text { of seeding, and } \\
\text { then apical side is exposed to the air, after which the } \\
\text { medium in basolateral side is changed every } 2 \text { days. }\end{array}$ \\
\hline $\begin{array}{l}\text { Morphological } \\
\text { appearance }\end{array}$ & $\begin{array}{l}\text { Flattened cell } \\
\text { (a lower epithelial thickness) }\end{array}$ & $\begin{array}{l}\text { Cubical or cobblestone appearance (much close to the } \\
\text { nasal tissue in vivo) }\end{array}$ \\
\hline $\begin{array}{l}\text { Cilia and mucin gene } \\
\text { expresson }\end{array}$ & $\begin{array}{l}\text { Denuded and flattened ciliated cells and numerous } \\
\text { microvillus are observed during } 3 \text { weeks. } \\
\text { Mucin gene expression is relatively weak. }\end{array}$ & $\begin{array}{l}\text { Significantly increased number of ciliated cells matured } \\
\text { with long and healthy cilia is observed after } 3 \text { weeks. } \\
\text { Stronger mucin gene expression compared to LCC } \\
\text { condition is observed. }\end{array}$ \\
\hline $\begin{array}{l}\text { TEER value } \\
\text { measurement }\end{array}$ & $\begin{array}{l}\text { Maximum TEER value (about 2,000 } \Omega \cdot \mathrm{cm}^{2} \text { ) is } \\
\text { appeared on day } 2 \text { and decreased quickly. }\end{array}$ & $\begin{array}{l}\text { Maximum TEER value }\left(>3,000 \Omega \cdot \mathrm{cm}^{2}\right) \text { iss appeared on } \\
\text { day } 5 \text {, and high TEER value }\left(>1,000 \Omega \cdot \mathrm{cm}^{2}\right) \text { is maintained } \\
\text { over } 10 \text { days. }\end{array}$ \\
\hline References & $\begin{array}{l}\text { Yoo et al., 2003, } \\
\text { Lin et al., } 2005\end{array}$ & $\begin{array}{l}\text { Lee et al., } 2005 \text {, } \\
\text { Lin et al., } 2007 \text {, } \\
\text { Huh et al., } 2010\end{array}$ \\
\hline
\end{tabular}

drugs. These results suggested that passaged primary human nasal epithelial cell monolayers could be used for in vitro drug transport study.

To verify the utility of the passaged cell culture model for nasal drug delivery, several anti-allergic drugs have been selected for transport study and the relationship between lipophilicity and permeability across the cell monolayer was observed (Lin et al., 2005). Permeability of model drugs on the established cell monolayer system was compared with reported results in porcine nasal mucosa to verify the application perspective of the passaged human nasal epithelial cell monolayer for drug transport study. $\mathrm{P}_{\text {app }}$ values of anti-allergic drugs in established human nasal epithelial cell monolayer were lower than those in porcine nasal mucosa. This discrepancy may be caused by the species differences between human and porcine tissues as well as different tight junctional properties. Nevertheless, a good log-linear relationship between $\mathrm{P}_{\text {app }}$ values in cell monolayer and lipophilicity index (i.e., $\log \mathrm{P}$ ) was presented indicating that lipophilicity of drugs was a critical factor for determining permeability in the nasal epithelial cell monolayer. And it also implied that this nasal epithelial cell monolayer could be used as an in vitro evaluation system for nasal drug delivery.

Functionally expressed tight junction, apical cilia expression, and mucin secretion are considered as important properties for in vitro nasal epithelial cell culture system. Ciliated cells also play an important role in the aspect of mucociliary function for nasal drug delivery. However, LCC culturing condition can produce relatively undifferentiated epithelial cells with few ciliated cells compared to in vivo nasal epithelium. Cell culture condition and cell culture media including additives (e.g., serum-free media and retinoic acid) for cell differentiation may promote similar cell differentiation pattern with the nasal epithelium.

ALI condition is attained by removing the culture media in the apical side of the monolayer. Unlike the LCC condition where the TEER value peaked on day 2 and declined to zero by day 15 (Lee et al., 2005), the TEER value under ALI condition peaked on day 5 (approximately $3,000 \Omega \cdot \mathrm{cm}^{2}$ ) and maintained constantly over $1,000 \Omega \cdot \mathrm{cm}^{2}$ by day 20 . These results indicated that ALI condition could provide better environment for drug transport studies compared to LCC conditions. Yet, the strongest advantage of the ALI condition was results showing differentiation into the ciliated cells, of which expression was observed in 21 days of culture. FBS and retinoic acid contained in BEGM/DME-F12 were reported to play essential roles in proliferation and differentiation, respectively. Additionally, ALI condition can deliver oxygen more efficiently across the thin film of liquid to the cells, consequently altering cellular respiration to a more aerobic state and improving the differentiation of nasal epithelial cells compared to LCC condition (Lin et al., 2005).

Drug transporters and enzyme expression in human nasal epithelial cell monolayers

Drug transporters and enzymes expressed in many organs and tissues of the human body generally influence drug absorption, distribution, metabolism and excretion. Because the nasal cavity is in contact with the atmosphere, it is assumed that enzymatic barriers or efflux transporters could be 
expressed in the nasal mucosa. Reports show that P-glycoprotein (P-gp), multidrug resistance-associated protein (MRP), organic anion transporter 6 , organic cation transporter were expressed in the nasal and olfactory mucosa of rat and bovine (Chemuturi and Donovan, 2007; Genter et al., 2010; Kaler et al., 2006; Kandimalla and Donovan, 2005). In the human nasal epithelium, the expression of P-gp and MRP1 was also identified (Henriksson et al., 1997; Wioland et al., 2000). These transporters can transport a large variety of hydrophobic and amphiphilic substances and it may be related with detoxification of xenobiotics instilled into the nasal cavity. However, it was noted that the P-gp expression level in the respiratory epithelium of human was lower (by 250-fold) than that in the liver (Bremer et al., 1992). The gene expression profiles of 11 ATP-binding cassette (ABC) transporters, 11 solute carrier (SLC) transporters and 9 solute carrier anion (SLCO) transporters in respiratory epithelial cell lines (Calu-3 and $16 \mathrm{HBE} 14 \mathrm{o}^{-}$) were reported (Endter et al., 2009). Especially, as one of the representative efflux transporters, the expression of P-gp was verified in 16HBE14o-, Calu-3, and normal human bronchial epithelial (NHBE) cell monolayer cultured by the air-liquid interface (ALI) method (Brouillard et al., 2001; Ehrhardt et al., 2003; Florea et al., 2001; Lin et al., 2007b).

Recently, the functional evidence and activity of P-gp expression in passaged primary human nasal epithelial cell monolayers cultured by the ALI method were reported (Cho et al., 2011b). In that report, MDR1 gene expression according to the cell culture period was demonstrated by RT-PCR assay. The functional activity of P-gp was proven by the cellular uptake and transport studies in human nasal epithelial cell monolayers cultured by ALI method with P-gp substrate (i.e., rhodamine 123) and P-gp inhibitors (i.e., verapamil and cyclosporine A). These results implied that this cell monolayer system was useful for predicting in vivo drug absorption in the nasal cavity, especially for the P-gp-mediated drug transport.

It is known that nasal delivery can avoid the hepatic firstpass effect, but enzymatic barrier in the nasal mucosa can cause a "pseudo-first-pass effect" (Sarkar et al., 1992). Airborne xenobiotics can be detoxified by cytochrome P-450 enzymes expressed in the nasal epithelium and the biotransformation of xenobiotics by P-450 enzymes is linked with toxicological effects, such as cancer. Various kinds of compounds can be metabolized by the nasal P-450-dependent monooxygenase system. Moreover, certain catalytic activity of the P450 enzymes is higher than in any other tissues including the liver. Although the existence of P-450 enzymes in human nasal mucosa was identified (Getchell et al., 1993), the expression of drug metabolizing enzymes in human nasal epithelial cell monolayer was not completely demonstrated. Further investigation on the expression of drug metabolizing enzymes and their function is required for this cell monolayer system to be applicable for drug metabolism studies.

\section{Application of human nasal epithelial cell monolayers for drug transport study}

Among respiratory epithelial cell lines, Calu-3 cell monolayer, which revealed ample tight junction formation and TEER values for the drug transport study, has been widely used for the evaluation of nasal drug delivery. The in vitro performance of dry powder (Bur et al., 2010), permeation enhancer (Amoako-Tuffour et al., 2009), liposome for vaccine delivery (Christensen et al., 2010), nanoparticles (Amidi et al., 2006; Teijeiro-Osorio et al., 2009) and microparticles and gels (Witschi and Mrsny, 1999) were evaluated in Calu-3 cell monolayers. Though RPMI 2650 cell line is a human nasal squamous cell carcinoma of the nasal septum, its utilization in drug transport study is restricted due to the lack of tight junction formation and insufficient TEER value. In recent drug transport studies in passaged primary human nasal epithelial cell monolayers, drug permeation enhancing effects could be correlated with the improvement of bioavailability in animal studies (Cho et al., 2010; Cho et al., 2011a; Huh et al., 2010; Lin et al., 2007), implying that the in vitro cell monolayer system could be used for the predicting in vivo performance. Considering that in vivo animal study requires large amounts of test samples and induces species differences and ethical problems, in vitro nasal epithelial cell monolayer system can be utilized as a high-throughput screening system for evaluating drug absorption in the nasal cavity once a reliable correlationship is established between the in vitro and in vivo results.

\section{Conclusions}

Nasal drug delivery has been investigated as an alternative administration route for oral and injection routes. Small molecular chemicals and biomacromolecules have been tested for delivery via the nasal route in various formulations. For the elucidation of drug transport mechanism and the investigation of metabolism and toxicity, diverse in vitro models of nasal cell culture systems have been developed. Calu-3 and RPMI 2650 cell lines have been widely used in the nasal drug transport study, but they have intrinsic drawbacks including improper origin and the lack of confluent cell monolayers. The human primary nasal cell system has also several limitations including difficulty in obtaining human nasal tissue, possibility of pathogen contamination and donor-to-donor variability. 
Therefore, serially passaged culture of human nasal epithelial cells could be an alternative to overcome these obstacles. Moreover, further studies on the ALI culture of passaged human nasal epithelial cell monolayer system could bring forth a reliable and facile means of evaluation of the in vitro nasal drug transport studies.

\section{Acknowledgements}

This work was supported by the Industrial Source Technology Development Program funded by the Ministry of Commerce, Industry and Energy (MOCIE) in Korea (Grant No. 10031825) and by the National Research Foundation (NRF) grant funded by the Korean government (MEST) (No. 20090083533).

\section{References}

Agu, R.U., Jorissen, M., Willems, T., Augustijns, P., Kinget, R., Verbeke, N., 2001. In-vitro nasal drug delivery studies: comparison of derivatised, fibrillar and polymerised collagen matrix-based human nasal primary culture systems for nasal drug delivery studies. J. Pharm. Pharmacol. 53, 1447-1456.

Agu, R.U., Jorissen, M., Willems, T., Van den Mooter, G., Kinget, R., Verbeke, N., Augustijns, P., 2000. Safety assessment of selected cyclodextrins - effect on ciliary activity using a human cell suspension culture model exhibiting in vitro ciliogenesis. Int. J. Pharm. 193, 219-226.

Agu, R.U., Obimah, D., Lyzenga, W., Jorissen, M., Massoud, E., Verbeke, N., 2009. Specific aminopeptidases of excised human nasal epithelium and primary culture: a comparison of functional characteristics and gene transcripts expression. J. Pharm. Pharmacol. 61, 599-606.

Agu, R.U., Vu Dang, H., Jorissen, M., Kinget, R., Verbeke, N., 2004. Metabolism and absorption enhancement of methionine enkephalin in human nasal epithelium. Peptides 25, 563-569.

Agu, R.U., Vu Dang, H., Jorissen, M., Willems, T., Kinget, R., Verbeke, N., 2002. Nasal absorption enhancement stratigies for therapeutic peptides: an in vitro study using cultured human nasal epithelium. Int. J. Pharm. 237, 179-191.

Alford, B.R., Douglas Jr., R.G., Couch, R.B., 1969. Atraumatic biopsy of nasal mucosa. Arch. Otolaryngol. 90, 180-184.

Amidi, M., Romeijn, S.G., Borchard, G., Junginger, H.E., Hennink, W.E., Jiskoot, W., 2006. Preparation and characterization of protein-loaded N-trimethyl chitosan nanoparticles as nasal delivery system. J. Control. Release 111, 107-116.

Amoako-Tuffour, M., Yeung, P.K., Agu, R.U., 2009. Permeation of losartan across human respiratory epithelium: an in vitro study with Calu-3 cells. Arch. Pharm. 59, 395-405.

Arora, P., Sharma, S., Garg, S., 2002. Permeability issues in nasal drug delivery. Drug Discov. Today 7, 967-975.

Bai, S., Yang, T., Abbruscato, T.J., Ahsan, F., 2008. Evaluation of human nasal RPMI 2650 cells grown at an air-liquid interface as a model for nasal drug transport studies. J. Pharm. Sci. 97, $1165-1178$.

Berger, J.T., Voynow, J.A., Peters, K.W., Rose, M.C., 1999. Respiratory carcinoma cell lines. MUC genes and glycoconjugates. Am. J. Respir. Cell Mol. Biol. 20, 500-510.

Bernstein, J.M., Yankaskas, J.R., 1994. Increased ion transport in cultured nasal polyp epithelial cells. Arch. Otolaryngol. Head Neck Surg. 120, 993-996.

Bitko, V., Barik, S., 2008. Nasal delivery of siRNA. Methods Mol. Biol. 442, 75-82.

Boucher, R.C., Cotton, C.U., Gatzy, J.T., Knowles, M.R., 1988. Evidence for reduced $\mathrm{Cl}^{-}$and increased $\mathrm{Na}^{+}$permeability in cystic fibrosis human primary cell cultures. J. Physiol. 405, 77103.

Boucher, R.C., Yankaskas, J.R., Cotton, C.U., Knowles, M.R., Stutts, M.J., 1987. Cell culture approaches to the investigation of human airway ion transport. Eur. J. Respir. Dis. Suppl. 153, 59-67.

Bremer, S., Hoof, T., Wilke, M., Busche, R., Scholte, B., Riordan, J.R., Maass, G., Tummler, B., 1992. Quantitative expression patterns of multidrug resistance P-glycoprotein (MDR1) and differentially spliced cyctic-fibrosis transmembrane-conductance regulator mRNA transcripts in human epithelia. Eur. J. Biochem. 206, 137-149.

Brouillard, F., Tondelier, D., Edelman, A., Baudouin-Legros, M., 2001. Drug resistance induced by ouabain via the stimulation of MDR1 gene expression in human carcinomatous pulmonary cells. Cancer Res. 61, 1693-1698.

Bur, M., Huwer, H., Muys, L., Lehr, C.M., 2010. Drug transport across pulmonary epithelial cell monolayers: effects of particle size, apical liquid volume, and deposition technique. J. Aerosol. Med. Pulm. Drug Deliv. 23, 119-127.

Chemuturi, N.V., Donovan, M.D., 2007. Role of organic cation transporters in dopamine uptake across olfactory and nasal respiratory tissues. Mol. Pharm. 4, 936-942.

Chen, M., Li, X.R., Zhou, Y.X., Yang, K.W., Chen, X.W., Deng, Q., Liu, Y., Ren, L.J., 2009. Improved absorption of salmon calcitonin by ultraflexible liposomes through intranasal delivery. Peptides. 30, 1288-1295.

Chen, Y., Zhao, Y.H., Wu, R., 2001. Differential regulation of airway mucin gene expression and mucin secretion by extracellular nucleotide triphosphates. Am. J. Respir. Cell Mol. Biol. 25, 409-417.

Cho, E., Gwak, H., Chun, I., 2008. Formulation and evaluation of ondansetron nasal delivery systems. Int. J. Pharm. 349, 101107.

Cho, H.J., Balakrishnan, P., Shim, W.S., Chung, S.J., Shim, C.K., Kim, D.D. 2010. Characterization and in vitro evaluation of freeze-dried microparticles composed of granisetron-cyclodextrin complex and carboxymethylcellulose for intranasal delivery. Int. J. Pharm. 400, 59-65.

Cho, H.J., Balakrishnan, P., Park, E.K., Song, K.W., Hong, S.S., Jang, T.Y., Kim, K.S., Chung, S.J., Shim, C.K., Kim, D.D. 
2011a. Poloxamer/cyclodextrin/chitosan-based thermoreversible gel for intranasal delivery of fexofenadine hydrochloride. J. Pharm. Sci. in press.

Cho, H.J., Choi, M.K., Lin, H., Kim, J.S., Chung, S.J., Shim, C.K., Kim, D.D. 2011. Expression and functional activity of P-glycoprotein (P-gp) in passaged primary human nasal epithelial (HNE) cell monolayers cultured by the air-liquid interface (ALI) method for nasal drug transport study. J. Pharm. Pharmacol.

Christensen, D., Foged, C., Rosenkrands, I., Lundberg, C.V., Andersen, P., Agger, E.M., Nielsen, H.M., 2010. CAF01 liposomes as a mucosal vaccine adjuvant: In vitro and in vivo investigations. Int. J. Pharm. 390, 19-24.

Cornaz, A.L., Buri, P., 1994. Nasal mucosa as an absorption barrier. Eur. J. Pharm. Biopharm. 40, 261-270.

Costantino, H.R., Illum, L., Brandt, G., Johnson, P.H., Quay, S.C., 2007. Intranasal delivery: physicochemical and therapeutic aspects. Int. J. Pharm. 337, 1-24.

Coste, A., Rateau, J., Roudot-Thoraval, F., Chapelin, C., Gilain, L., Poron, F., Peynegre, R., Bernaudin, J., Escudier, E., 1996. Increased epithelial cell proliferation in nasal polyps. Arch. Otolaryngol. Head Neck Surg. 122, 432.

Cozens, A.L., Yezzi, M.J., Kunzelmann, K., Ohrui, T., Chin, L., Eng, K., Finkbeiner, W.E., Widdicombe, J.H., Gruenert, D.C., 1994. CFTR expression and chloride secretion in polarized immortal human bronchial epithelial cells. Am. J. Respir. Cell. Mol. Biol. 10, 38-47.

De Fraissinette, A., Brun, R., Felix, H., Vonderscher, J., Rummelt, A., 1995. Evaluation of the human cell line RPMI 2650 as an in vitro nasal model. Rhinology. 33, 194-198.

Dimova, S., Vlaeminck, V., Brewster, M.E., Noppe, M., Jorissen, M., Augustijns, P., 2005. Stable ciliary activity in human nasal epithelial cells grown in a perfusion system. Int. J. Pharm. 292, 157-168.

Ehrhardt, C., Kneuer, C., Fiegel, J., Hanes, J., Schaefer, U.F., Kim, K.J., Lehr, C.M., 2002. Influence of apical fluid volume on the development of functional intercellular junctions in the human epithelial cell line 16HBE140-: implications for the use of this cell line as an in vitro model for bronchial drug absorption studies. Cell. Tissue. Res. 308, 391-400.

Ehrhadt, C., Kneuer, C., Laue, M., Schaefer, U.F., Kim, K.J., Lehr, C.M., 2003. 16HBE14o- human bronchial epithelial cell layers express P-glycoprotein, lung resistance-related protein, and caveolin-1. Pharm. Res. 20, 545-551.

Endter, S., Francombe, D., Ehrhardt, C., Gumbleton, M., 2009. RTPCR analysis of ABC, SLC and SLCO drug transporters in human lung epithelial cell models. J. Pharm. Pharmacol. 61, 583-591.

Florea, B.I., van der Sandt, I.C., Schrier, S.M., Kooiman, K., Deryckere, K., de Boer, A.G., Junginger, H.E., Borchard, G., 2001. Evidence of P-glycoprotein mediated apical to basolateral transport of flunisolide in human broncho-tracheal epithelial cells (Calu-3). Br. J. Pharmacol. 134, 1555-1563.

Foster, K.A., Avery, M.L., Yazdanian, M., Audus, K.L., 2000.
Characterization of the Calu-3 cell line as a tool to screen pulmonary drug delivery. Int. J. Pharm. 208, 1-11.

Genter, M.B., Krishan, M., Augustine, L.M., Cherrington, N.J., 2010. Drug transporter expression and localization in rat nasal respiratory and olfactory mucosa and olfactory bulb. Drug Metab. Dispos. 38, 1644-1647.

Gervasi, P., Longo, V., Naldi, F., Panattoni, G., Ursino, F., 1991. Xenobiotic-metabolizing enzymes in human respiratory nasal mucosa. Biochem. Pharmacol. 41, 177-184.

Getchell, M.L., Chen, Y., Ding, X., Sparks, D.L., Getchell, T.V., 1993. Immunohistochemical localization of a cytochrome P450 isozyme in human nasal mucosa: age-related trends. Ann. Otol. Rhinol. Laryngol. 102, 368-374.

Gray, T.E., Guzman, K., Davis, C.W., Abdullah, L.H., Nettesheim, P., 1996. Mucociliary differentiation of serially passaged normal human tracheobronchial epithelial cells. Am. J. Respir. Cell Mol. Biol. 14, 104-112.

Gray, T., Koo, J.S., Nettesheim, P., 2001. Regulation of mucous differentiation and mucin gene expression in the tracheobronchial epithelium. Toxicology 160, 35-46.

Gruenert, D.C., Basbaum, C.B., Widdicombe, J.H., 1990. Longterm culture of normal and cystic fibrosis epithelial cells grown under serum-free conditions. In Vitro Cell. Dev. Biol. 26, 411-418.

Han, D., Wang, N., Zhang, L., 2009. The effect of myrtol standardized on human nasal ciliary beat frequency and mucociliary transport time. Am. J. Rhinol. Allergy 23, 610-614.

Hanamure, Y., Deguchi, K., Ohyama, M., 1994. Ciliogenesis and mucus synthesis in cultured human respiratory epithelial cells. Ann. Otol. Rhinol. Laryngol. 103, 889-895.

Harikarnpakdee, S., Lipipun, V., Sutanthavibul, N., Ritthidej, G.C., 2008. Spray-dried mucoadhesive microspheres: preparation and transport through nasal cell monolayer. AAPS PharmSciTech. 7, 12.

Henriksson, G., Norlander, T., Zheng, X., Stierna, P., Westrin, K.M., 1997. Expression of P-glycoprotein 170 in nasal mucosa may be increased with topical steroids. Am. J. Rhinol. 11, $317-$ 321.

Hofmann, T., Reinisch, S., Gerstenberger, C., Koele, W., Gugatschka, M., Wolf, G, 2010. Influence of topical antifungal drugs on ciliary beat frequency of human nasal mucosa: an in vitro study. Laryngoscope. 120, 1444-1448.

Hoang, V.D., Uchenna, A.R., Mark, J., Renaat, K., Norbert, V., 2002. Characterization of human nasal primary culture systems to investigate peptide metabolism. Int. J. Pharm. 238, 247-256.

Hood, A.T., Currie, D., Garte, S.J., 1987. Establishment of a rat nasal epithelial tumor cell line. In Vitro Cell. Dev. Biol. 23, 274-278.

Hosoya, K., Kubo, H., Natsume, H., Sugibayashi, K., Morimoto, Y., 1994. Evaluation of enhancers to increase nasal absorption using Ussing chamber technique. Biol. Pharm. Bull. 17, 316322.

Howard, K.A., Rahbek, U.L., Liu, X., Damgaard, C.K., Glud, S.Z., 
Andersen, M.Ø., Hovgaard, M.B., Schmitz, A., Nyengaard, J.R., Besenbacher, F., Kjems, J., 2006. RNA interference in vitro and in vivo using a novel chitosan/siRNA nanoparticle system. Mol. Ther. 14, 476-484.

Huh, Y., Cho, H.J., Yoon, I.S., Choi, M.K., Kim, J.S., Oh, E., Chung, S.J., Shim, C.K., Kim, D.D., 2010. Preparation and evaluation of spary-dried hyaluronic acid microspheres intranasal delivery of fexofenadine hydrochloride. Eur. J. Pharm. Sci. 40, 9-15.

Hull, J., Harris, A., 1994. Limitations of cell culture of airway epithelium collected by a nasal brushing technique. In Vitro Cell. Dev. Biol. 30A, 488-489.

Jintapattanakit, A., Peungvicha, P., Sailasuta, A., Kissel, T., Junyaprasert, V.B., 2010. Nasal absorption and local tissue reaction of insulin nanocomplexes of trimethyl chitosan derivatives in rats. J. Pharm. Pharmacol. 62, 583-591.

Kaler, G., Truong, D.M., Sweeney, D.E., Logan, D.W., Nagle, M., Wu, W., Eraly, S.A., Nigam, S.K., 2006. Olfactory mucosaexpressed organic anion transporter, Oat6, manifests high affinity interactions with odorant organic anions. Biochem. Biophys. Res. Commun. 351, 872-876.

Kandimallar, K.K., Donovan, M.D., 2005. Localization and differential activity of P-glycoprotein in the bovine olfactory nasal respiratory mucosae. Pharm. Res. 22, 1121-1128.

Kienast, K., Riechelmann, H., Knorst, M., Schlegel, J., MüllerQuernheim, J., Schellenberg, J., Ferlinz, R. 1994. An experimental model for the exposure of human ciliated cells to sulfur dioxide at different concentrations. Clin. Investig. 72, 215219.

Kissel, T., Werner, U., 1998. Nasal delivery of peptides: an in vitro cell culture model for the investigation of transport and metabolism in human nasal epithelium. J. Control. Release 53, 195203.

Koizumi, J., Kojima, T., Ogasawara, N., Kamekura, R., Kurose, M., Go, M., Harimaya, A., Murata, M., Osanai, M., Chiba, H., Himi, T., Sawada, N., 2008. Protein kinase C enhances tight junction barrier function of human nasal epithelial cells in primary culture by transcriptional regulation. Mol. Pharmacol. 74, 432-442.

Lang, S., Langguth, P., Oschmann, R., Traving, B., Merkle, H.P., 1996. Transport and metabolic pathway of thymocartin (TP4) in excised bovine nasal mucosa. J. Pharm. Pharmacol. 48, 1190-1196.

Lazard, D.S., Moore, A., Hupertan, V., Martin, C., Escabasse, V., Dreyfus, P., Burgel, P.R., Amselem, S., Escudier, E., Coste, A., 2009. Muco-ciliary differentiation of nasal epithelial cells is decreased after wound healing in vitro. Allergy 64, 1136-1143.

Lee, M.K., Yoo, J.W., Lin, H., Kim, Y.S., Kim, D.D., Choi, Y.M., Park, S.K., Lee, C.H., Roh, H.J., 2005. Air-liquid interface culture of serially passaged human nasal epithelial cell monolayer for in vitro drug transport studies. Drug Deliv. 12, 305-311.

Leitner, V.M., Guggi, D., Krauland, A.H., Bernkop-Schnürch, A., 2004. Nasal delivery of human growth hormone: in vitro and in vivo evaluation of a thiomer/glutathione microparticulate delivery system. J. Control. Release 100, 87-95.

Li, L., Mathias, N.R., Heran, C.L., Moench, P., Wall, D.A., Smith, R.L., 2006. Carbopol-mediated paracellular transport enhancement in Calu-3 cell layers. J. Pharm. Sci. 95, 326-335.

Lin, H., Gebhardt, M., Bian, S., Kwon, K.A., Shim, C.K., Chung, S.J., Kim, D.D., 2007. Enhancing effect of surfactants on fexofenadine $\cdot \mathrm{HCl}$ transport across the human nasal epithelial cell monolayer. Int. J. Pharm. 330, 23-31.

Lin, H., Li, H., Cho, H.J., Bian, S., Roh, H.J., Lee, M.K., Kim, J.S., Chung, S.J., Shim, C.K., Kim, D.D., 2007b. Air-liquid interface (ALI) culture of human bronchial epithelial cell monolayers as an in vitro model for airway drug transport studies. J. Pharm. Sci. 96, 341-350.

Lin, H., Yoo, J.W., Roh, H.J., Lee, M.K., Chung, S.J., Shim, C.K., Kim, D.D., 2005. Transport of anti-allergic drugs across the passage cultured human nasal epithelial cell monolayer. Eur. J. Pharm. Sci. 26, 203-210.

Mallant, R., Jorissen, M., Augustijns, P., 2008. Beneficial effect of antibiotics on ciliary beat frequency of human nasal epithelial cells exposed to bacterial toxins. J. Pharm. Pharmacol. 60, 437-443.

Mallant, R., Vlaeminck, V., Jorissen, M., Augustijns, P., 2009. An improved primary human nasal cell culture for the simultaneous determination of transepithelial transport and ciliary beat frequency. J. Pharm. Pharmacol. 61, 883-890.

Manford, F., Tronde, A., Jeppsson A.B., Patel, N., Johansson, F., Forbes, B., 2005. Drug permeability in 16HBE14o- airway cell layers correlates with absorption from the isolated perfused rat lung. Eur. J. Pharm. Sci. 26, 414-420.

Marttin, E., Verhoef, J.C., Merkus, F.W., 1998. Efficacy, safety and mechanism of cyclodextrins as absorption enhancers in nasal delivery of peptide and protein drugs. J. Drug Target. 6, 17-36.

Mathia, N.R., Timoszyk, J., Stetsko, P.I., Megill, J.R., Smith R.L., Wall, D.A., 2002. Permeability characteristics of calu-3 human bronchial epithelial cells: in vitro-in vivo correlation to predict lung absorption in rats. J. Drug Target. 10, 31-40.

Minn, A., Leclerc, S., Heydel, J.M., Denizot, C., Cattarelli, M., Netter, P., Gradinaru, D., 2002. Drug transport into the mammalian brain: the nasal pathway and its specific metabolic barrier. J. Drug Target. 10, 285-296.

Noruddin, N.A.A., Saim, A.B., Chua, K.H., Idrus, R., 2007. Human nasal turbinates as a viable source of respiratory epithelial cells using co-culture system versus dispase-dissociation technique. Laryngoscope 117, 2139-2145.

Otsuka, H., Dolovich, J., Richardson, M., Bienenstock, J., Denburg, J.A., 1987. Metachromatic cell progenitors and specific growth and differentiation factors in human nasal mucosa and polyps. Am. Rev. Respir. Dis. 136, 710-717.

Pipkorn, U., Karlsson, G., Enerbäck, L., 1988. A brush method to harvest cells from the nasal mucosa for microscopic and biochemical analysis. J. Immunol. Methods 112, 37-42.

Pipkorn, U., Karlsson, G., 1988. Methods for obtaining specimens from the nasal mucosa for morphological and biochemical analysis. Eur. Respir. J. 1, 856-862. 
Pires, A., Fortuna, A., Alves, G., Falcão, A., 2009. Intranasal drug delivery: how, why and what for? J. Pharm. Pharm. Sci. 12, 288-311.

Robinson, C.B., Wu, R., 1993. Mucin synthesis and secretion by cultured tracheal cells: effects of collagen substratum thickness. In Vitro Cell. Dev. Biol. Anim. 29A, 469-477.

Roh, H.J., Goh, E.K., Wang, S.G., Chon, K.M., Yoon, J.H., Kim, Y.S., 1999. Serially passaged normal human nasal epithelial cells: morphology and mucous secretory differentiation. Korean. J. Rhinol. 6, 107-112.

Sarkar, M.A., 1992. Drug metabolism in the nasal mucosa. Pharm Res. 9, 1-9.

Merkle, H.P., Ditzinger, G., Lang, S.R., Peter, H., Schmidt, M.C., 1998. In vitro cell models to study nasal mucosal permeability and metabolism. Adv. Drug Deliv. Rev. 29, 51-79.

Seki, T., Kanbayashi, H., Chono, S., Tabata, Y., Morimoto, K., 2007. Effects of sperminated gelatin on the nasal absorption of insulin. Int. J. Pharm. 338, 213-218.

Slütter, B., Bal, S., Keijzer, C., Mallants, R., Hagenaars, N., Que, I., Kaijzel, E., van Eden, W., Augustijns, P., Löwik, C., Bouwstra, J., Broere, F., Jiskoot, W., 2010. Nasal vaccination with N-trimethyl chitosan and PLGA based nanoparticles: nanoparticle characteristics determine quality and strength of the antibody response in mice against the encapsulated antigen. Vaccine 28, 6282-6291.

Steele, V.E., Arnold, J.T., 1985. Isolation and long-term culture of rat, rabbit, and human nasal terbinate epithelial cells. In Vitro Cell. Dev. Biol. 21, 681-687.

Suptawiwat, O., Tantilipikorn, P., Boonarkart, C., Lumyongsatien, J., Uiprasertkul, M., Puthavathana, P., Auewarakul, P., Brown, J., 2010. Enhanced susceptibility of nasal polyp tissues to avian and human influenza viruses. PLoS One 5: e12973

Teijeiro-Osorio, D., Remuñán-López, C., Alonso, M.J., 2009. New generation of hybrid poly/oligosaccharide nanoparticles as carriers for the nasal delivery of macromolecules. Biomacromolecules 10, 243-249.

Usui, S., Shimizu, T., Kishioka, C., Fujita, K., Sakakura, Y., 2000. Secretory cell differentiation and mucus secretion in cultures of human nasal epithelial cells: use of a monoclonal antibody to study human nasal mucin. Ann. Otol. Rhinol. Laryngol. 109, 271-277.

Vetter, A., Martien, R., Bernkop-Schnürch, A., 2010. Thiolated polycarbophil as an adjuvant for permeation enhancement in nasal delivery of antisense nucleotides. J. Pharm. Sci. 99, 1427-1439.

Vu Dang, H., Agu, R.U., Jorissen, M., Kinget, R., Verbeke, N., 2002. Characterization of human nasal primary culture systems to investigate peptide metabolism. Int. J. Pharm. 238. 247-256.

Wadell, C., Bjork, E., Camber, O., 1999. Nasal drug delivery-evaluation of an in vitro model using porcine nasal mucosa. Eur. J. Pharm. Sci. 7, 197-206.

Wadell, C., Bjork, E., Camber, O., 2003. Permeability of porcine nasal mucosa correlated with human nasal absorption. Eur. J.
Pharm. Sci. 18, 47-53.

Wengst, A., Reichl, S., 2010. RPMI 2650 epithelial model and three-dimensional reconstructed human nasal mucosa as in vitro models for nasal permeation studies. Eur. J. Pharm. Biopharm. 74, 290-297.

Werner, U., Kissel, T., 1995. Development of a human nasal epithelial cell culture model and its suitability for transport and metabolism studies under in vitro conditions. Pharm. Res. 12, 565-571.

Werner, U., Kissel, T., 1996. In-vitro cell culture models of the nasal epithelium: a comparative histochemical investigation of their suitability for drug transport studies. Pharm. Res. 13, 978988.

Wilk-Blaszczak, M.A., French, A.S., Man, S.F., 1992. Halide permeation through $10 \mathrm{pS}$ and $20 \mathrm{pS}$ anion channels in human airway epithelial cells. Biochim. Biophys. Acta. 1104, 160166.

Wioland, M.A., Fleury-Feith, J., Corlieu, P., Commo, F., Monceaux, G., Lacau-St-Guily, J., Bernaudin, J.F., 2000. CFTR, MDR1, and MRP1 immunolocalization in normal human nasal respiratory mucosa. J. Histochem. Cytochem. 48, 12151222.

Witschi, C., Mrsny, R.J., 1999. In vitro evaluation of microparticles and polymer gels for use as nasal platforms for protein delivery. Pharm. Res. 16, 382-390.

Wu, R., Yankaskas, J., Cheng, E., Knowles, M.R., Boucher, R., 1985. Growth and differentiation of human nasal epithelial cells in culture. Serum-free, hormone-supplemented medium and proteoglycan synthesis. Am. Rev. Respir. Dis. 132, 311320.

Wüthrich, P., Buri, P., 1989. The transnasal route of drug administration. Aspects of nasal anatomy and physiology. Pharm. Acta. Helv. 64, 322-331.

Yang, T., Hussain, A., Paulson, J., Abbruscato, T.J., Ahsan, F., 2004. Cyclodextrins in nasal delivery of low-molecular-weight heparins: in vivo and in vitro studies. Pharm. Res. 21, 11271136.

Yankaskas, J.R., Cotton, C.U., Knowles, M.R., Gatzy, J.T., Boucher, R.C., 1985. Culture of human nasal epithelial cells on collagen matrix supports. A comparison of bioelectric properties of normal and cystic fibrosis epithelia. Am. Rev. Respir. Dis. 132, 1281-1287.

Yeo, N.K., Jang, Y.J., 2010. Rhinovirus infection-induced alteration of tight junction and adherens junction components in human nasal epithelial cells. Laryngoscope 120, 346-352.

Yoo, J.W., Kim, Y.S., Lee, S.H., Lee, M.K., Roh, H.J., Jhun, B.H., Lee, C.H., Kim, D.D., 2003. Serially passaged human nasal epithelial cell monolayer for in vitro drug transport studies. Pharm. Res. 20, 1690-1696.

Yoon, J.H., Kim, K.S., Kim, S.S., Lee, J.G., Park, I.Y., 2000. Secretory differentiation of serially passaged normal human nasal epithelial cells by retinoic acid: expression of mucin and lysozyme. Ann. Otol. Rhinol. Laryngol. 109, 594-601.

Yu, H., Kim, K., 2009. Direct nose-to-brain transfer of a growth 
hormone releasing neuropeptide, hexarelin after intranasal administration to rabbits. Int. J. Pharm. 378, 73-79.

Zhou, H., Wang, X., Brighton, L., Hazucha, M., Jaspers, I., Carson, J.L., 2009. Increased nasal epithelial ciliary beat frequency associated with lifestyle tobacco smoke exposure. Inhal. Tox- icol. $21,875-881$.

Zuckerman, J.D., Lee, W.Y., DelGaudio, J.M., Moore, C.E., Nava, P., Nusrat, A., Parkos, C.A., 2008. Pathophysiology of nasal polyposis: the role of desmosomal junctions. Am. J. Rhinol. 22, 589-597. 